Anna Grzywa

Akademia Ignatianum, Kraków

e-mail: grzywaania@gmail.com

DOI: http://dx.doi.org/10.12775/BPTh.2015.020

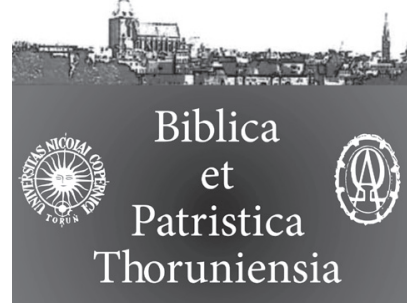

$8(2015) 3$

ISSN (print) 1689-5150

ISSN (online) 2450-7059

\title{
Świeccy towarzyszący katechumenom na drodze do sakramentu chrztu, analiza zagadnienia na podstawie wybranych, starożytnych źródeł katechumenalnych
}

\section{The laity accompanying catechumens on their way to the sacrament of baptism, the analysis of the notion on the basis of selected ancient catechumenal sources}

\begin{abstract}
Streszczenie. Katechumenom na ich drodze prowadzącej do przyjęcia sakramentu chrztu towarzyszyli ludzie świeccy, których zakres zadań zmieniał się wraz z rozwojem przygotowania przedchrzcielnego, następującego w kolejnych wiekach. Artykuł wskazuje miejsca i etapy w formacji katechumenalnej, gdzie rola osób świeckich była szczególnie podkreślana. Wśród tych osób możemy umownie mówić o trzech konkretnych grupach, do których należeli: świadkowie, rodzice oraz wspólnota wiernych, rozumiana jako zgromadzenie, w obecności którego następuje wtajemniczenie w Święte Obrzędy. W istocie grupy te pełniły bardzo podobne funkcje, wspierając katechumenów w czasie ich przygotowań.
\end{abstract}

\begin{abstract}
While preparing for receiving the sacrament of baptism catechumens were accompanied by the laity whose range of responsibilities transformed along with development of the pre-baptismal preparation, following the subsequent centuries. The article indicates places and phases in the catechumenal formation, where the role of the laity was particularly emphasised. As far as those people are taken into consideration, it is possible to indicate three particular groups to which belonged: witnesses, parents and the community of the faithful, perceived as an assembly in borders of which an initiation into the sacred rites occured. In fact, these groups played similar roles, supporting catechumens during their preparation.
\end{abstract}


Słowa kluczowe: katechumenat starożytny; świeccy; świadkowie; ojcowie chrzestni; ojcowie duchowni; wspólnota wiernych; sakrament chrztu; Ojcowie Kościoła; początki chrześcijaństwa.

Keywords: ancient catechumenate; laity; witnesses; sponsors; spiritual fathers; community of faithful; baptism; fathers of the church; beginnings of Christianity.

$\mathrm{P}$ roblemem, którym chciałam poddać analizie, będzie rola świeckich towarzyszących katechumenom w czasie drogi prowadzącej do sakramentu chrztu. Moim zadaniem będzie wskazanie miejsc i etapów w formacji, w czasie których poświadcza i uzasadnia się ich obecność oraz zmianę rozumienia pełnionych przez nich funkcji, zaobserwowaną na przestrzeni rozwoju przygotowania przedchrzcielnego w kolejnych wiekach.

Analizując źródła dotyczące starożytnego katechumenatu, możemy dostrzec osoby świeckie, towarzyszące katechumenom na drodze do wtajemniczenia chrześcijańskiego. W sposób umowny przyporządkowuje je do trzech grup. Są to przede wszystkim bliskie osoby określane w zależności od miejsca i czasu jako świadkowie, gwaranci, poręczyciele, rodzice chrzestni czy ojcowie duchowni. Kolejną wyróżnioną grupę stanowią najbliżsi, czyli rodzice. Na końcu należy wspomnieć też o zadaniach całej wspólnoty kościelnej, rozumianej jako zgromadzenie wiernych, w obecności której katechumeni są wtajemniczani w Święte Obrzędy. Wszystkie wymienione przeze mnie grupy pełniły w istocie bardzo podobne funkcje $\mathrm{w}$ przygotowaniach przedchrzcielnych, jedynie wraz $\mathrm{z}$ rozwojem instytucji katechumenatu zmienia się zakres powierzonym im przez Kościół obowiązków.

\section{Świadkowie}

Od samego początku katechumenatu zgłaszający chęć wejścia do Kościoła był zobowiązany przybyć razem ze świadkiem potwierdzającym jego szczere intencje. Szczegółowo przytacza ten zwyczaj Tradycja Apostolska, dokument z początku III wieku w słowach:

Nowo przybyłych, zgłaszających się na katechezę należy zaraz przyprowadzić do nauczyciela, zanim jeszcze lud się zbierze. Nauczyciel zapyta ich o motywy, jakie ich skłoniły do szukania wiary, ci zaś, którzy ich przyprowadzili, złożą oświadczenie o ich zdolności słuchania nauk ${ }^{1}$.

1 Tradycja Apostolska, 15. 
Kim byli ci świadkowie? Z całą pewnością to chrześcijanie, którzy bardzo dobrze znali zgłaszających się. Być może to oni przyczynili się do nawrócenia kandydatów, stąd teraz mogą stać się wiarygodnymi poręczycielami ich szczerych intencji. Jak słusznie zauważa ks. Murawski ${ }^{2}$, autor Tradycji nie podaje jeszcze ich nazwy, opisuje jedynie ich funkcję jako tych, którzy przyprowadzają - ...qui adducunt. Bardzo szczegółowe badanie kandydatów, z którym nie spotkamy się już w żadnym innym miejscu i czasie, nawet w tzw. złotym okresie katechumenatu, wskazuje na dużą odpowiedzialność spoczywającą na poręczających oraz na fakt, że od początku Kościół przykładał wagę do ich świadectwa. Znaczenie tej funkcji było też pewnego rodzaju nowością przynoszoną przez chrześcijan, stąd świadek z Tradycji Apostolskiej jest kimś innym niż np. ten spotykany podczas chrztu prozelitów. U prozelitów był on jedynie świadkiem legalności chrztu ${ }^{3}$, podczas gdy tutaj musiał potwierdzić wiarygodność nawrócenia kandydata. Najprawdopodobniej poręczyciel pozostawał w bliskiej relacji $\mathrm{z}$ katechumenem podczas całego okresu jego formacji, odbywanego, jak podaje Tradycja Apostolska przez trzy lata, o czym świadczy powołanie się na jego opinię przy kolejnym egzaminie:

Wybrawszy tych, którzy mogą być dopuszczeni do chrztu, należy jeszcze stwierdzić jak prowadzili się oni w okresie katechumenatu: czy żyli bogobojnie, czy szanowali wdowy, odwiedzali chorych, pełnili dobre uczynki? Jeśli poświadczą to ci, którzy ich przyprowadzili, można ich dopuścić do słuchania Ewangelii ${ }^{4}$.

Jako potwierdzenie istnienia zwyczaju towarzyszenia kandydatowi na jego drodze przygotowań możemy zinterpretować także fragment $\mathrm{z}$ traktatu Orygenesa Przeciw Celsusowi. Pisze on tak:

Chrześcijanie natomiast, jeśli to jest możliwe, przede wszystkim badają duszę tych, którzy ich pragną słuchać i uczą ich najpierw na osobności; a gdy uczniowie jeszcze nieprzyjęci do wspólnoty wykażą postępy w pragnieniu uczciwego życia, wówczas przyjmują ich tworząc oddzielną grupę początkujących i świeżo przyjętych, którzy nie otrzymali jeszcze symbolu oczyszczenia, i oddzielną grupę tych, którzy wedle swych sił postępowaniem swoim udowodnili, iż nie pragną niczego innego, tylko tego, co wyznają chrześcijanie.

2 R. Murawski SDB, Historia katechezy, s. 189.

3 E. Ferguson, Baptism In the Early Church, s. 367.

4 Tradycja Apostolska, 17. 
Wśród tej drugiej grupy niektórzy mają obowiązek czuwania nad życiem i postępowaniem kandydatów, aby nie dopuścić tych, którzy są winni wykroczeń, uczciwych zaś serdecznie przyjmować i czynić ich z dnia na dzień lepszymi ${ }^{5}$.

W przytoczonym fragmencie, który jest częścią dłuższej argumentacji, Orygenes broni sposobu nauczania praktykowanego przez chrześcijan, którym zarzucano, że wybierają swoich słuchaczy w przypadkowy i nieprzemyślany sposób. Odpowiadając na zarzuty Celsusa, autor pokazuje, że w Kościele funkcjonuje pewien ustalony i przemyślany system, wewnątrz którego znajdują się także czuwający nad przygotowującymi się, a którym możemy przypisać rolę świadków. Czyni to na tyle skutecznie, że badacze dopatrują się w jego argumentacji bliskiego formalnego podziału na dwie grupy katechumenów wraz z egzaminowaniem ich sposobu życia ${ }^{6}$.

Następnie, w okresie intensywnego rozwoju katechumenatu datowanego na IV wiek spotykamy kilka aspektów powodujących poszerzenie rozumienia funkcji gwarantów. Szczególnie interesująca pod tym względem staje się Antiochia. Analizując źródła dostępne z tego rejonu, możemy dostrzec, że wprawdzie świadkowie dalej towarzyszą katechumenom na ich drodze nawrócenia, są potrzebni, aby potwierdzić Kościołowi ich zmianę, ale akcent kładziony jest także na gwarancję dotyczącą przyszłego życia. Tym samym ich funkcja dodatkowo sprowadza się do bycia przewodnikami w życiu chrześcijańskim, następującym już po przyjęciu sakramentu, co wcześniej nie było brane pod uwagę i zaznaczane. Ks. Mokrzycki idzie nawet o krok dalej w interpretacji, podkreślając, że rola gwaranta zaczyna się tak naprawdę dopiero w momencie chrztu i stąd w założeniu powinna realizować się powoli w dalszym życiu neofity ${ }^{7}$. Jan Chryzostom, wybitny kaznodzieja, autor katechez chrzcielnych wygłoszonych prawdopodobnie jeszcze jako kapłan antiocheński w latach miedzy 388 a 397, zwraca uwagę na rolę gwarantów przedstawiając ją właśnie w aspekcie odpowiedzialności, która się przed nimi otwiera. Bezpośrednio do nich kieruje słowa:

Pozwólcie, że zwrócę się teraz do tych, którzy odpowiadają za was, aby i oni wiedzieli, na jaką zasługują nagrodę za troskę względem was, a jaką karę ściągają za niedbalstwo ${ }^{8}$.

5 Orygenes, Przeciw Celsusowi, 3,51.

6 P.F. Bradshaw, Reconstructing Early Christian Worship, s. 56.

7 Ks. B. Mokrzycki, Droga chrześcijańskiego wtajemniczenia, , s. 141.

8 Jan Chryzostom, katecheza II, 15. 


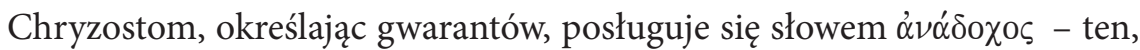
który otrzymuje. Ten prawniczy termin oznacza tego, który jest gwarantem i ręczy za pożyczającego jedną trzecią sumy9 ${ }^{9}$ Tym samym świadkowie mają za zadanie potwierdzić, że osoba, za która poświadczają, właściwie użyje dóbr, którymi zostanie obdarowana. Co więcej, poręczyciel chrztu powinien być bardziej ostrożny niż poręczyciel prawny, a jego zadaniem jest pokazywanie ojcowskiej miłości przez zachęty i napominanie tych, którzy mają przejść poręczenia $^{10}$. Dalej argumentuje:

Niech nie myślą, że chodzi tu o rzeczy błahe, ale niech wiedzą, że będzie im się należało uznanie, jeśli powierzonych sobie swoimi upomnieniami poprowadzą drogą cnoty, a za niedbalstwo spotkają się z naganą. Stąd nazywa się ich ojcami duchownymi, aby dali sobie sprawę, jak troskliwie winni zaznajamiać z rzeczami duchowymi tych, których im dano w opiekę ${ }^{11}$.

Używane przez autora określenie ojcowie duchowni jest nowym zwrotem, niespotykanym wcześniej w kontekście poręczycieli chrzcielnych. To nasuwa pytanie, czy w związku z tym nastąpiła też zmiana w rozumieniu posługi gwaranta. Przypuszczano, że u Chryzostoma, choć nie jest to wprost pokazane, funkcja ta związana była także w jakiś szczególny sposób ze sprawowaniem egzorcyzmów ${ }^{12}$. Świadczyć ma o tym umieszczenie specjalnego słowa do gwarantów między wyjaśnieniem celu i symboliki egzorcyzmu a deklaracją wyrzeczenia się Szatana. Moim zdaniem jednak, z braku wystarczających dowodów, możemy przypuszczać, że było to jedynie towarzyszenie egzorcyzmowanym. Zwłaszcza, że prawdopodobnie z powodu wielkiej liczby kandydatów, akt wyrzeczenia się złego ducha przeniesiono potem na Wielki Piątek po południu.

Teodor z Mopsuestii, przyjaciel Jana Chryzostoma jest także autorem katechez chrzcielnych, co do których badacze nie są zgodni kiedy i gdzie powsta$\mathrm{ły}^{13}$, ale niewątpliwie możemy zaliczyć je do tradycji antiocheńskiej. Do dziś w języku syryjskim zachowało się jego 16 homilii katechetycznych, wśród których trzy wyjaśniają przebieg liturgii chrztu. Autor podkreśla, że świadkowie, czyli specjalni wyznaczone osoby, powinni gwarantować gotowość kandydata

9 J. Pollok, Liturgia chrztu na Wschodzie, s. 41.

10 P.W. Harkins, Pre-Baptismal Rites, s. 224.

11 Jan Chryzostom, katecheza II, 16.

12 R.F.G. Burnish, The Role of the Godfather, s. 559.

13 Wsród hipotez podaje się m.in., iż mogły zostać wygłoszone w Antiochii przed 392 r., w Syrii ok. 392 r. lub w Mopsuestii między 392 a 428. 
do przyjęcia chrztu ${ }^{14}$. Nasuwa się $\mathrm{w}$ tym punkcie pytanie, według jakich zasad mogło przebiegać to wyznaczenie? Wydaje się z kontekstu katechez, że była to sprawa indywidualna, oparta na osobistym prowadzeniu i trosce o przygotowującego się. Jak zaznacza dalej Teodor, świadkowie nie biorą odpowiedzialności za grzechy katechumenów, które popełnią w przyszłości, są przywoływani, aby zaświadczyć o dotychczasowym życiu formowanych. Ale zaraz dodaje, podobnie jak Jan Chryzostom, posługując się przemawiającym do wyobraźni słuchaczy porównaniem, że gwarant powinien stać się jakby przewodnikiem po mieście i zaznajomić swojego podopiecznego z zasadami tam panującymi ${ }^{15}$. To miasto, którego obywatelami mają się stać katechumeni przez chrzest to niebieskie Jeruzalem, symbolizujące Kościół. A zatem moim zdaniem przyjaciele patrzą na rolę gwaranta w bardzo podobny sposób, stąd nie wydaje mi się słuszny punkt widzenia reprezentowany przez Pietro Rentincka, który twierdzi, że między nimi nie ma zgody ${ }^{16}$. Być może jego opinia jest wnioskiem płynącym z porównania i przytoczenia tylko części poglądów tych autorów, jeśli jednak analizujemy całość katechez chrzcielnych w kontekście posługi świadka, to choć różnią się zarówno stylem jak pewnymi szczegółami dotyczącymi przebiegu celebracji katechumenalnych, nie może ujść uwadze zgodność ich myślenia. O tym samym pisze ks. Starowieyski, kiedy stwierdza, że, ich świadectwa podkreślają różne aspekty tej funkcji, ale w końcu obydwa nakładają się na siebie, tworząc jedną całość ${ }^{17}$.

Następny ważny element warty zanotowania, dotyczy przesunięcia momentu, w którym spotykamy się z służbą gwarantów. Są oni przywoływani już nie w chwili wejścia kandydatów do katechumenatu, ale w czasie rytu wpisania imienia tzw. nomendatio. Fakt ten potwierdza Egeria, w swojej z pewnością bogatszej w szczegóły niż katechezy Ojców, relacji z pielgrzymki do Ziemi Świętej, datowanej na ok. 384 rok. Pisze tak:

Gdy zatem prezbiter spisze imiona wszystkich, wtedy następnego dnia Wielkiego Postu, kiedy zaczyna się owych osiem tygodni, pośrodku większego kościoła, to jest Martyrium ustawia się tron dla biskupa. $Z$ obu stron zasiadają na krzesłach prezbiterzy, (inni) duchowni stoją. Przyprowadza się zgłoszonych (do chrztu), jednego po drugim. Jeśli są to mężczyźni - przychodzą ze swymi ojcami, jeśli kobiety z matkami.

Teodor z Mopsuestii, homilia XII, 14.

15 Teodor z Mopsuestii, homilia XII, 15.

16 P. Rentinck, La Cura Pastorale, s. 39.

17 M. Starowieyski, wstęp [w:] Jan Chryzostom, Katechezy chrzcielne, s. 14. 
Biskup szczegółowo wypytuje krewnych tych, którzy przybyli mówiąc: „Czy dobrze żyje, czy jest posłuszny rodzicom, czy nie oddaje się pijaństwu lub próżności?” Pyta też o poszczególne cięższe grzechy ludzkie.

Jeśli okaże się, że jest nienaganny w sprawach, o które go pytano wobec świadków, zapisuje on swoje imię własną ręką. Kiedy jednak jest o coś oskarżony (biskup) nakazuje mu wyjść, mówiąc „Niech się poprawi, a gdy się poprawi, wtedy przystąpi do chrztu” W ten sam sposób przemawia wypytując mężczyzn i niewiasty. Jeśli zaś ktoś jest cudzoziemcem i nie ma świadków, którzy by go znali, nie tak łatwo może być dopuszczony do chrztu ${ }^{18}$.

Prawda, że w tekście czytamy o rodzicach, jednak prawdopodobnie chodzi tu o instytucję rodziców chrzestnych, czyli świadków. W starożytnym katechumenacie rodzice biologiczni przywoływani są zazwyczaj w kontekście chrztu małych dzieci. Tutaj charakter zadawanych pytań sugeruje, że kandydaci byli już dorośli ${ }^{19}$ i odpowiedzialni za swoje czyny, stąd bardziej logiczne wydaje się towarzystwo bliskich, przyjaciół, a na pewno, osób bardzo dobrze im znanych.

Przeniesienie momentu świadectwa gwarantów nie powinno dziwić, jeśli weźmiemy pod uwagę zmieniające się okoliczności funkcjonowania okresu przygotowania do chrztu. W tym czasie, wolnym od prześladowań, w którym chrześcijaństwo powoli stawało się pierwszą religią w Imperium, tak wielu pozostawało przez długie lata w bezpiecznym katechumenacie, że potwierdzenia świadków potrzebowano dopiero przy decyzji oznaczającej przejście do grupy bezpośrednio przygotowujących się do chrztu. Poważnym potwierdzeniem tej decyzji był ryt wpisania imienia, czyli tzw. nomendatio. Znaczenie postaci gwaranta obecnego przy tej celebracji potwierdza fakt, że także jego imię, obok imienia katechumena było zapisywane do kościelnej księgi ${ }^{20}$.

Konstytucje Apostolskie, dokument także $\mathrm{z}$ Antiochii, datowany na ok. 380 rok zdaje się przedstawiać trochę inną sytuację. Otóż rolę świadków przejęły tam osoby duchowne. Kandydaci do chrztu powinni najpierw zgłosić się do diakonów, którzy przedstawią ich biskupowi lub prezbiterom ${ }^{21}$, oczywiście wcześniej zapoznawszy się szczegółowo z ich sytuacją życiową i motywami nimi kierującymi. Jak rozumieć podobną zmianę? Moim zdaniem dokument ten powinniśmy odczytywać, pamiętając o etapie rozwoju katechumenatu z którego pochodzi. „Klerykalizacja”, której doszukują się badacze ${ }^{22}$ wydaje się nie być celem samym w sobie, ani zewnętrznym wpływem, ale stanowić pró-

18 Egeria, Pielgrzymka do miejsc świętych, 45.

19 J. Wilkinson, Egeria’s Travels, s. 62.

20 Teodor z Mopsuestii, homilia XII, 16.

21 Konstytucje Apostolskie VIII, 32,2.

22 R. Murawski SDB, Historia katechezy, s. 311. 
bę zaostrzenia dyscypliny katechumenalnej, coraz trudniejszej do utrzymania wskutek szerokiej rzeszy chętnych, pragnących wejść do Kościoła z wielu różnych pobudek. Tym samym diakon, jako członek kleru, a stąd osoba znana i zaufana, wydawał się najwłaściwszym gwarantem mogącym zbadać i potwierdzić szczerość intencji zgłaszającego się. I choć nie są nam bliżej znane przypadki nadużyć pochodzące $\mathrm{z}$ tamtego okresu, ale zapewne musiały mieć miejsce przy tak wielu osobach zgłaszających się do Kościoła, prawdopodobnie dlatego wprowadzono podobną praktykę.

Niestety, w kolejnych wiekach coraz trudniejszą do przeprowadzenia była skuteczna weryfikacja przygotowania katechumenów. Wprawdzie dostrzegano potrzebę zaświadczenia o szczerych intencjach kandydata, jednak w rzeczywistości doświadczano licznych problemów, aby przeprowadzić podobne badanie. Augustyn z całą rozwagą katechety zaleca:

Rozumie się, że dobrze jest, aby ci, którzy znają nawracającego się, powiadomili nas przedtem, o ile możności, $w$ jakim on jest stanie umysłu, oraz jakimi przyczynami pobudzony przychodzi przyjąć naszą religię. Jeśli nie ma kogo innego, kto by dał nam to poznać, należy jego samego zapytać, abyśmy z tego, co odpowie wyprowadzili początek wykładu ${ }^{23}$.

Widzimy, jak duże rozluźnienie dyscypliny katechumenalnej nastąpiło na przestrzeni nawet niecałych pięćdziesięciu lat, gdyż jeszcze Egeria zapewniała, że bez odpowiedniego świadka nie tak łatwo być przyjętym do wspólnoty Kościoła. Augustyn powołuje się przede wszystkim na odpowiedzialność każdego człowieka za swoje czyny. Z drugiej strony podkreśla wielką rolę katechety, który nawet $\mathrm{z}$ nieczystych intencji kandydata przez łagodne upomnienie i jasny wykład może sprowadzić go na właściwą drogę.

\section{Rodzice}

Możemy zaryzykować stwierdzenie, że w ostatnim okresie funkcjonowania katechumenatu, rozumianego od ok. VI wieku, znaczną część odpowiedzialności gwarantów przejęli rodzice. Zmiana była nieuchronnie konsekwencją faktu, że do chrztu zaczęło przystępować coraz więcej dzieci, które jeszcze początkowo przyjmowały sakrament razem ze swoimi rodzicami. Poważny problem u schyłku katechumenatu polegał na niedostosowaniu celebracji liturgicznych do wieku kandydatów, co w konsekwencji doprowadziło do zagubienia sensu

23 Augustyn, Poczatkowe nauczanie religii V,9. 
istnienia instytucji gwaranta rozumianej $w$ takiej formie jak do tej pory. Ryty katechumenalne funkcjonujące dobrze nawet w okresie, kiedy do Kościoła wstępowały rzesze chętnych, tutaj stały się gestami nieprzemawiającymi już zarówno do dzieci jak i do dorosłych.

Jeszcze na początku VI wieku możemy dostrzec, wydaje się, ostatnie próby jasnej oceny sytuacji. Z około 500 roku pochodzi świadectwo diakona Jana, prawdopodobnie późniejszego papieża Jana I (523-526), który w liście do dostojnika Senariusza z Ravenny stara się odpowiedzieć na wątpliwości pytającego, także te dotyczące inicjacji chrześcijańskiej. Moim zdaniem sposób przedstawienia przez niego celebracji, jaką były ryty skrutinium wskazuje, że to właśnie one zastąpiły poniekąd funkcję gwarantów. Diakon pisze tak:

W następnej kolejności, zgodnie ze zwyczajem Kościoła, występują momenty zwane skrutiniami. Czynimy tak, aby wybadać ich serca w świetle wiary, w celu ustalenia czy od czasu wyrzeczenia się diabła święte słowa przeniknęły ich umysły ${ }^{24}$.

A zatem dla Jana skrutinia, w przeciwieństwie do rozumienia ich funkcji w poprzednich wiekach ${ }^{25}$, stały się osobistym badaniem będących na ostatnim etapie przygotowań, stąd nazwanych już nie katechumenami, ale wybranymi. $\mathrm{W}$ ten sposób sprawdzano, czy rzeczywiście skrutiniowani wykazują zmianę postawy i potwierdzają swoim życiem gotowość przyjęcia sakramentu, czyli dokładnie to, o co poprzednio pytano świadków. Podobne rozważanie możemy odnieść jedynie do środowiska rzymskiego, z którego pochodzi przytaczane źródło, co tym samym nie oznacza, iż wszędzie w tym samym czasie sytuacja była tak samo trudna. $Z$ tego samego okresu posiadamy świadectwo Ferrandusa z Kartaginy (zm. 531), który w liście do biskupa Fulgencjusza wspomina o grupie dorosłych competentes w Afryce, przechodzących jeszcze regularny katechumenat ${ }^{26}$.

Moim zdaniem list Jana stanowi próbę duszpasterskiego rozeznania sytuacji katechumenów. Diakon przytomnie stwierdza, że wszystkie opisywane przez niego ryty są czynione nawet nad niemowlętami, które z powodu swojego wieku nic nie rozumieją. Tym samym, kiedy są prezentowani Kościołowi przez rodziców czy innych (zapewne rodziców chrzestnych lub bliskie osoby) staje się konieczne, aby ich zbawienie było zależne od wyznania wiary innych ludzi ${ }^{27}$. Biorąc pod uwagę charakter całego listu, według mnie jest to przykład

John the Deacon 4, [w:] E.C. Whitaker, Documents of The Baptismal Liturgy.

Por. G.Cavalotto, Catecumenato antico,s. 277.

Epist. ad Fulg. ep. XI, PL 65,378.

John the Deacon 7, [w:] Documents of The Baptismal Liturgy. 
podkreślenia odpowiedzialności ciążącej nad rodzicami dzieci, postawionych wobec nowej sytuacji. Są jednak badacze, którzy widzą w tym fragmencie jedynie świadectwo powszechnego już w tym czasie chrztu dzieci.

Analizując dostępne źródła z późniejszych wieków, a w tym wypadku powołując się na księgi liturgiczne Sakramentarz Gelazjański z VI wieku i Ordo Romanus XI z VII wieku, odnoszące się także do środowiska rzymskiego, możemy zanotować $\mathrm{z}$ pewnym zdziwieniem, że celebracje są sprawowane właściwie już tylko nad dziećmi, które z konieczności przemawiają ustami swoich rodziców. Dostrzegamy ślady rytów celebrowanych w poprzednich wiekach z wielką starannością, jednak tu niedostosowanych do zmienionej sytuacji, a przez to niezrozumiałych dla uczestników. Wprawdzie imiona rodziców (bądź rodziców chrzestnych) są jeszcze zapisywane w księdze kościelnej i odczytywane ${ }^{28}$, podczas modlitwy wiernych, ale jest to właściwie już tylko pusty gest. Podobnie rodzice (oraz pojawiający się obok nich rodzice chrzestni, o których jednak nie możemy nic bliższego powiedzieć, stąd nasuwa się wątpliwość czy rzeczywiście odgrywali jakąś rolę) towarzyszą swoim dzieciom w rytach, które straciły swoje dotychczasowe znaczenie. Tak jak w czasie rozwoju katechumenatu, także tutaj wtajemniczani kandydaci nie mogli uczestniczyć w całej Eucharystii. Zatem zgodnie ze przestrzeganym zwyczajem, rodzice wychodzili na zewnątrz z dziećmi, oddając je opiece zaufanych osób, sami natomiast wracali do Kościoła na dalszą część celebracji ${ }^{29}$. Wciąż spotykamy się z uroczystym wezwaniem diakona podczas liturgii, aby wszyscy katechumeni opuścili miejsce zgromadzenia. Problem polega na tym, że tutaj przygotowujący są zbyt mali, aby zrozumieć czego się od nich oczekuje. Podobna sytuacja nie mogła trwać wiecznie, jednak zamiast próby refleksji i zmiany, doprowadziła ostatecznie do zaniku formacji katechumenalnej.

\section{Wspólnota wiernych}

Ostatnim elementem, o którym należy wspomnieć, jest wspólnota świeckich, tworzących Kościół, która towarzyszyła katechumenom na drodze ich chrześcijańskiej inicjacji. Świadomość jej roli wzrasta wraz z rozwojem instytucji katechumenatu. W Tradycji Apostolskiej czytamy o pierwszym egzaminie kandydatów, który odbywał się w towarzystwie świadków, ale jeszcze bez udziału $\operatorname{ludu}^{30}$. Wszystkie kolejne celebracje, jak się wydaje, mają już miejsce wobec

28 Ordo Romanus XI, 34, [w:] Documents of the Baptismal Liturgy.

29 Ordo Romanus XI,73, [w:] Documents of the Baptismal Liturgy.

30 Tradycja Apostolska, 15. 
wspólnoty wierzących, której członkowie przeszli wcześniej tę samą drogą, w której towarzyszą teraz kandydatom. Jean Danielou jasno podkreśla, że przygotowanie do chrztu bez wspólnoty towarzyszącej kandydatom nie miałoby wielkiej wartości ${ }^{31}$.

Odpowiedzialność wspólnoty, rozumianej jako pewna całość sprowadzała się zasadniczo do dwóch zadań. Były to publiczna, wspólna modlitwa za katechumenów i bycie świadkiem celebracji, które powinny doprowadzić kandydatów do świadomego przygotowania i przyjęcia sakramentu.

Ojcowie wskazywali na wyraźne rozróżnienie: katechumeni nie mogą jeszcze modlić się razem z wierzącymi, ani przekazywać im znaku pokoju. Jednak cała wspólnota, nie tylko prezbiterzy jest wzywana do modlitwy za kandydatów, przez co wyraża się troska i odpowiedzialność za przygotowujących się.

Moim zdaniem obecność wiernych wydaje się być szczególnie widoczna podczas rytu redditio, znanego i praktykowanego w Kościele od IV wieku. Celebracja polegała na wyrecytowaniu z pamięci przez katechumena Symbolu wiary, który wcześniej został mu objaśniony i przekazany przez katechetę w ceremonii określanej jako przekazanie, czyli traditio. Był to czas, w którym wybrani byli już na ostatnim etapie przygotowań, tuż przed przyjęciem sakramentu. Warto podkreślić, że w tym przypadku cała wspólnota pełniła niejako funkcję gwaranta. Symbol wiary był pewnego rodzaju jej skrótem, przedstawionym w sposób zwarty i kompletny, stąd jego wyrecytowanie przez wiernych wobec zgromadzenia stanowiło pewną weryfikację, stwierdzającą, iż kandydat dobrze opanował podstawy chrześcijańskiej nauki. Z pewnością też zadaniem wspólnoty była swego rodzaju kontrola czy przygotowujący się nie osłabili przez jakieś zniekształcenie prawowitości jego brzmienia ${ }^{32}$.

Symbol musiał być oddany tzn. wyrecytowany przed całym zgromadzeniem, w skład którego wchodzili wybrani i ci, którzy już przystąpili do sakramentu. Dopuszczano jednak pewne wyjątki w przyjętej procedurze. Jak przytacza Augustyn w Wyznaniach, w Rzymie istniał zwyczaj, zgodnie z którym, kandydaci, dla których publiczna ceremonia mogłaby być zbyt kłopotliwa otrzymywali pozwolenie, aby wyznanie wiary złożyć prywatnie. Z takiej możliwości nie skorzystał słynny retor Wiktoryn, a tym samym jego świadectwo, według relacji Augustyna stało się manifestacją wiary i wywołało niezwykłe poruszenie i radość wśród wszystkich zebranych ${ }^{33}$.

U schyłku katechumenatu dostrzegamy wypaczenie tego rytu. Redditio Symboli jest praktykowane w dalszym ciągu wobec całego zgromadzenia, jed-

31 J. Danielou SI, La catechesi nei primi secoli, s. 44.

32 L. Gładyszewski, wstęp: [w:] Ambroży z Mediolanu, Wyjaśnienie Symbolu, s. 30.

33 Augustyn, Wyznania, VIII, 2. 
nak w zastępstwie katechumenów, którymi są praktycznie już tylko dzieci, wyznanie wiary wygłasza akolita. Przechodząc obok dzieci rozdzielonych na dwie grupy według płci, kładł rękę na ich głowie i śpiewał: wierzę w Boga ${ }^{34}$. Jest to kolejny przykład zagubienia istoty rytu, tym samym rola wspólnoty jako świadka dojrzałości i przygotowania kandydata traci swoje dotychczasowe znaczenie. Cała odpowiedzialność za przekazanie wiary spoczywa więc na rodzicach i rodzicach chrzestnych.

Krótko podsumowując, warto wskazać jeszcze raz istotę rozważanego zagadnienia. Przede wszystkim widać wyraźnie, że kandydat nie mógł przejść całej drogi katechumenalnej bez pomocy osób świeckich, wśród których wymienia się nie tylko najbliższych, pojedyncze konkretne osoby, ale także całą wspólnotę wiernych. Sama instytucja świadka przeszła konkretną ewolucję, od osoby poświadczającej o godnym życiu zgłaszającego się, przez potwierdzenie gotowości kandydata do chrztu, aż do ojca duchowego roztaczającego opiekę nad chrześcijańskim życiem neofity, co jest najbliższe współczesnemu rozumieniu funkcji rodziców chrzestnych.

\section{Bibliografia}

\section{Źródła}

Ambroży z Mediolanu, Wyjaśnienie Symbolu, o tajemnicach, o sakramentach, przeł. L. Gładyszewski, ŹMT 31, Wydawnictwo WAM, Kraków 2004.

Augustyn, Poczatkowe nauczanie religii [w:] Pisma katechetyczne, przeł. ks. St. Budzik, PAX, Warszawa 1952.

Augustyn, Wyznania, przeł. Z. Kubiak, Wydawnictwo Znak, Kraków 2007.

Documents of The Baptismal Liturgy, ed. Whitaker E.C., S.P.C.K., London 1970.

Egeria, Pielgrzymka do miejsc świętych [w:] Do Ziemi Świętej. Najstarsze opisy pielgrzymek do Ziemi Świętej IV-VIII w., przeł. P. Iwaszkiewicz, Wydawnictwo WAM, Kraków 2010.

Epistola XI, s. Fulgentii Episcopi Ruspensis, [w:] PL 65, Migne, Paris 1847.

Jan Chryzostom, Katechezy chrzcielne, U źródeł katechumenatu 1, Wydawnictwo Kerygma, Lublin 1993.

Konstytucje Apostolskie [w:] Konstytucje Apostolskie oraz Kanony Pamfilosa z apostolskiego synodu w Antiochii. Prawo Kanoniczne Świętych Apostołów. Kary Świętych Apostołów dla upadłych. Euchologion Serpiona, przeł. St. Kalinkowski, SCL 2, Wydawnictwo WAM, Kraków 2007.

34 Ordo Romanus XI, 62, [w:] Documents of the Baptismal Liturgy. 
Orygenes, Przeciw Celsusowi, przeł. S. Kalinkowski, PSP 17, Wydawnictwo ATK, Warszawa 1977.

Teodor z Mopsuesti, Le Omelie Battesimali e Mistagogiche Di Teodoro Di Mopsuestia, Coop San Tommaso, Messina 2008.

Tradycja Apostolska, [w:] Antologia Literatury Patrystycznej, t. I, oprac. ks. M. Michalski, PAX, Warszawa 1975.

\section{Opracowania}

Bradshaw P. F., Reconstructing Early Christian Worship, SPCK: London, 2009.

Burnish R.F.G., The Role of the Godfather in the East in the Fourth Century [w:] Studia Patristica XVII, part 2, ed. E.A. Livingstone, Pergamon Press, 1982.

Cavalotto G., Catecumenato antico. Diventare cristiani secondo Padri, Edizioni Dehoniane Bologna, Bologna 1996.

Danielou J. SI, La catechesi nei primi secoli, Elle di CI Torino-Leumann, Torino 1968.

Ferguson E., Baptism In the Early Church. History, Theology, and Liturgy in the First Five Centuries, Willim B. Eerdmans Publishing Company, USA: Grand Rapids, Michigan/Cambridge U.K. 2009.

Harkins P.W., Pre-Baptismal Rites In Chrisostom's Baptismal Catechesis, [w:] Studia Patristica VII, Akademie Verlag: Berlin, 1966.

Mokrzycki B. ks, Droga chrześcijańskiego wtajemniczenia, ATK, Warszawa 1983.

Murawski R. SDB, Historia katechezy. Katecheza w pierwszych wiekach, Wydawnictwo Salezjańskie, Warszawa 2011.

Pollok J., Liturgia chrztu na Wschodzie w drugiej połowie IV wieku na podstawie mistagogicznych homilii Cyryla Jerozolimskiego, Jana Chryzostoma i Teodora z Mopsuestii, Studia Antiquitatis Christianae 10, ATK, Warszawa 1992.

Rentinck P., La Cura Pastorale in Antiochia nel IV Secolo, Universita Gregoriana Editrice, Roma 1970.

Wilkinson J., Egeria's Travels to the Holy Land, Ariel Publishing House, Jerusalem 1981. 